\title{
Transcriptome Sequencing Reveals the Differentially Expressed lncRNAs and mRNAs Involved in Cryoinjuries in Frozen-Thawed Giant Panda (Ailuropoda melanoleuca) Sperm
}

\author{
Ming-Xia Ran ${ }^{1,+}$, Yuan Li ${ }^{1,+}$, Yan Zhang ${ }^{1}$, Kai Liang ${ }^{1}$, Ying-Nan Ren ${ }^{1}$, Ming Zhang ${ }^{1}$, \\ Guang-Bin Zhou ${ }^{1}$, Ying-Min Zhou ${ }^{2}$, Kai Wu ${ }^{2}$, Cheng-Dong Wang ${ }^{2}$, Yan Huang ${ }^{2}$, Bo Luo ${ }^{2}$, \\ Izhar Hyder Qazi ${ }^{1,3}{ }^{-0}$, He-Min Zhang ${ }^{2}$ and Chang-Jun Zeng ${ }^{1, *(1)}$ \\ 1 College of Animal Sciences and Technology, Sichuan Agricultural University, \\ Chengdu 611130, Sichuan, China; 18227585649@163.com (M.-X.R.); LY13072840231@163.com (Y.L.); \\ yanzhang@sicau.edu.cn (Y.Z.); sicau-liangkai@hotmail.com (K.L.); J1450544201@163.com (Y.-N.R.); \\ zhm3000@126.com (M.Z.); zguangbin@sicau.edu.cn (G.-B.Z.); vetdr_izhar@yahoo.com (I.H.Q.) \\ 2 China Conservation and Research Center for the Giant Panda, Wolong 473000, China; \\ zhouyingmin3552@hotmail.com (Y.-M.Z.); Woki1213@163.com (K.W.); wonsir@gmail.com (C.-D.W.); \\ pandayard@hotmail.com (Y.H.); boluo911@126.com (B.L.); hmhm_zhang@163.com (H.-M.Z.) \\ 3 Department of Veterinary Anatomy \& Histology, Faculty of Bio-Sciences, Shaheed Benazir Bhutto University \\ of Veterinary and Animal Sciences, Sakrand 67210, Pakistan \\ * Correspondence: zengchj@sicau.edu.cn; Tel./Fax: +86-28-8629-1010 \\ $\dagger$ These authors contribute equally to this work.
}

Received: 5 September 2018; Accepted: 5 October 2018; Published: 8 October 2018

\begin{abstract}
Sperm cryopreservation and artificial insemination are important methods for giant panda breeding and preservation of extant genetic diversity. Lower conception rates limit the use of artificial insemination with frozen-thawed giant panda sperm, due to the lack of understanding of the cryodamaging or cryoinjuring mechanisms in cryopreservation. Long non-coding RNAs (lncRNAs) are involved in regulating spermatogenesis. However, their roles during cryopreservation remain largely unexplored. Therefore, this study aimed to identify differentially expressed lncRNAs and mRNAs associated with cryodamage or freeze tolerance in frozen-thawed sperm through high throughput sequencing. A total of $61.05 \mathrm{~Gb}$ clean reads and 22,774 lncRNA transcripts were obtained. From the sequencing results, 1477 significantly up-regulated and 1,396 significantly down-regulated lncRNA transcripts from fresh and frozen-thawed sperm of giant panda were identified. GO and KEGG showed that the significantly dysregulated lncRNAs and mRNAs were mainly involved in regulating responses to cold stress and apoptosis, such as the integral component of membrane, calcium transport, and various signaling pathways including PI3K-Akt, p53 and cAMP. Our work is the first systematic profiling of lncRNA and mRNA in fresh and frozen-thawed giant panda sperm, and provides valuableinsights into the potential mechanism of cryodamage in sperm.
\end{abstract}

Keywords: giant panda; IncRNA; mRNA; frozen-thawed sperm; transcriptome sequencing

\section{Introduction}

The giant panda (Ailuropoda melanoleuca) is an endangered species confined to south-central China. Natural mating and artificial insemination are common approaches for breeding of the giant panda in captivity. Artificial insemination has been proven to play an important role in assisted reproduction in humans and other mammals. However, the artificial insemination of giant pandas mainly employs fresh sperm, while frozen-thawed sperm is rarely used in this procedure. The lower farrowing rate also 
explains the poor utilization efficiency of giant panda frozen-thawed sperm. Furthermore, only about $25 \%(3 / 11)$ of giant pandas at the ideal breeding age are mating naturally [1]. The genetic management of captive giant panda is recognized as one of the highest priorities of ex-situ conservation action in China. The ability to consistently produce offspring using cryopreserved sperm would make substantial improvement to giant panda breeding as cryopreserved sperm can be stored for a longer time [2]. It has been reported that more than $30 \%$ of frozen-thawed sperm can be utilized for artificial insemination with successful conception and birth of giant panda [3]. For example, 4 out of 7 giant pandas were pregnant after artificial insemination performed by Huang and co-authors, yielding a breeding success rate of $57.1 \%$ [4].

Substantial efforts have also been made on the selection and screening of cryoprotectants, antioxidants and freeze-thawing programs [5-8]. Through exploring different freezing diluents (TEST sucrose, egg yolk and glycerol), freezing methods, and thawing solutions, a new procedure for preparing $0.25 \mathrm{~mL}$ frozen panda semen was established [5]. Giant panda sperm appears to be strongly cryo-resistant and can survive repeated cycles of freezing-thawing [9]. However, the pregnancy rate of insemination using frozen-thawed semen was only $28.57 \%$, which is less than the $33.3 \%$ observed in insemination using fresh semen and in natural mating [3]. A loss in sperm motility immediately after thawing was observed compared with the pre-freeze motility in giant panda sperm. More sperms were capacitated than fresh sperms after the freezing procedure [2]. However, the mechanism of freeze-tolerance and cryoinjury in giant panda sperm remains unclear.

Mature sperm cells contain RNA [10], and might retain certain transcriptional and translational activities [11,12]. Gur and Breitbart have demonstrated that protein expression from nuclear genes does, in fact, occur in sperm. Both mRNAs and their translated proteins were observed to be localized inside and outside of the mitochondria $[13,14]$. It has also been shown that ejaculated sperms can translate protein from mRNA transcripts during the final maturation steps prior to fertilization. Besides, knocking down the hyperactivation-associated mRNA by transfecting siRNA can inhibit the level of cAMP and protein oxidative phosphorylation in spermatozoa and reduce the level of sperm hyperactivation $[15,16]$. Recently, microRNA (miRNA) and long non-coding RNA (lncRNA) have been demonstrated to be involved in spermatogenesis [17], sperm cryoinjuries [18] and fertility [19]. The non-coding RNA with length greater than 200 nucleotides is defined as lncRNA [20]. Numerous evidences have shown that IncRNA is a novel regulatory gene that plays important roles in cell development, pluripotency, cell growth and apoptosis [21-25]. Furthermore, IncRNA is also crucial in the regulation of sperm function. As illustrated by microarray analysis, lncRNA is regulated dynamically and is expressed mainly in meiosis and haploid stages during spermatogenesis [26]. The survival rate of spermatogonial stem cell was significantly decreased when lncRNA033862 was knocked out [27]. In addition, apoptosis of spermatocytesin pachytene was increased after Tsx knockout [28]. Furthermore, IncRNA HOTAIR could increase the activity of superoxide dismutase (SOD) in human sperm by enhancing Nrf2 expression, which could ultimately affect sperm quality [29]; Over-expression of mil-HongrES2, sheared from HongrES2, could affect sperm capacitation by inhibiting the expression of CES7 [30]. Differential expressions of lncRNA and mRNA between diabetic and normal sperm, along with its role in the diabetes-related low fertility, were also uncovered by high throughput sequencing and lncRNA-mRNA interaction studies [31].

To date, the contribution of IncRNA and mRNA in the regulation of cold response in cryopreserved giant panda sperm has yet to be elucidated. Here, we employed a high throughput sequencing approach to explore the expression profiles of mRNA and lncRNAs in fresh and frozen-thawed giant panda sperm, with the goal to better understand the potential role of differentially expression of lncRNAs and mRNA in sperm cryoinjury or cryodamage during cryopreservation. 


\section{Result}

\subsection{Sperm Quality before and after Cryopreservation}

The average volume of electro-ejaculation was $2.50 \pm 0.35 \mathrm{~mL}$ with concentration of $16.71 \pm 4.36$ $\times 10^{8} \mathrm{~mL}^{-1}$. The sperm motility was significantly decreased from $0.83 \pm 0.08$ to $0.63 \pm 0.10$ before and after cryopreservation, respectively $(p<0.05)$.

\subsection{RNA Quality Inspection}

RNA integrity was assessed using the RNA Nano 6000 Assay Kit of the Agilent Bioanalyzer 2100 System (Agilent Technologies, Santa Clara, CA, USA) (Figure 1).
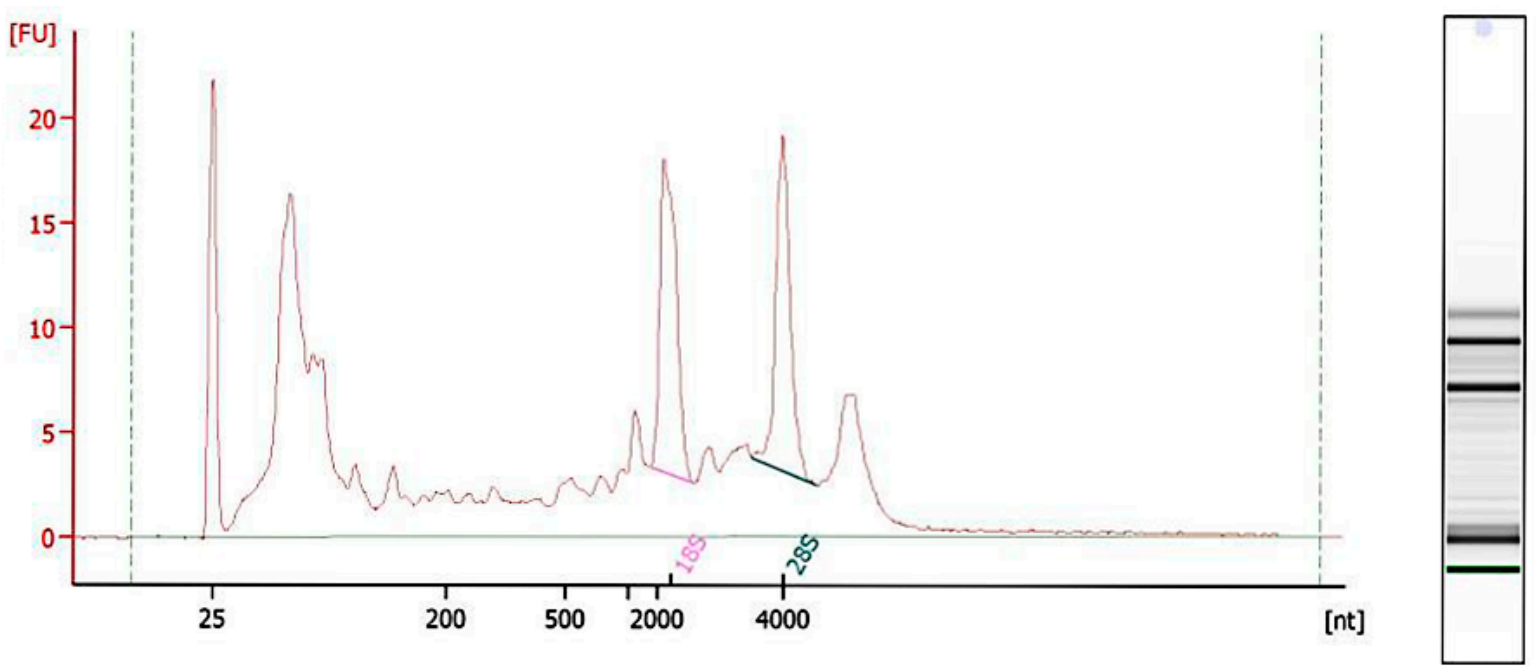

Figure 1. RNA integrity analyzes of giant panda sperm showed $28 \mathrm{~S}$ and $18 \mathrm{~S}$.

\subsection{RNA Sequencing Roundup}

After sequencing quality control, we obtained $61.05 \mathrm{~Gb}$ of clean data, and the Q30 base percentages of each sample were no less than $89.25 \%$. The mapping rate of blasted fresh and frozen-thawed sperm to the latest giant panda reference genome were $46.30 \%$ and $57.78 \%$, respectively.

\subsection{Identification of $\ln c R N A$ s and $m R N A$}

The qualified transcripts were analyzed using the CNCI, CPC and Pfam-scan software. We identified a total of 22,774 lncRNAs (Figure 2a), among which 16,110 of them were lincRNAs including 1086 antisense lncRNAs, 4369 intronic lncRNAs, and 1209 sense lncRNA (Figure 2b). In addition, 32,322 protein-coding transcripts were also identified, which contains 13,186 new genes (Tables S1 and S2). 


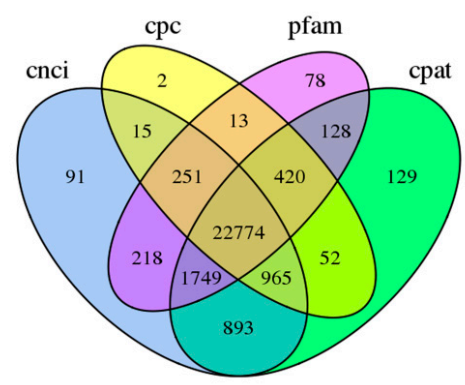

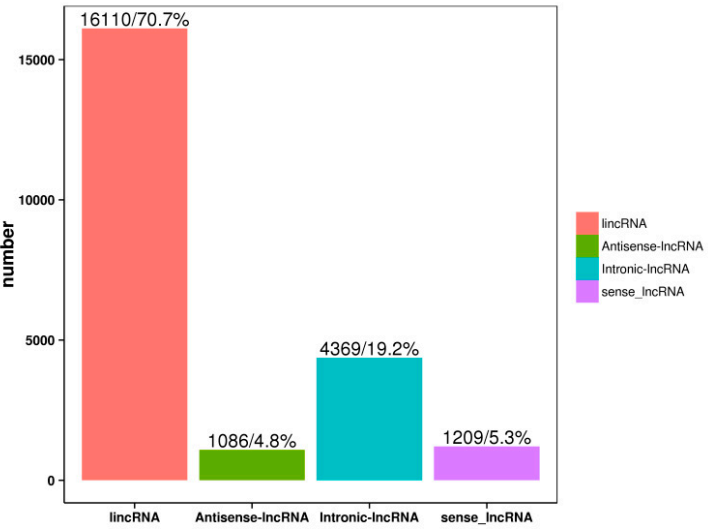

Figure 2. (a) Coding potential analysis of Venn diagram. Four tools (CNCI, CPC, CPAT and Pfam-scan) were selected to analyze the coding potential of lncRNAs. The data shared by the four tools were designated as candidates for subsequent analyses. (b) The identified lncRNAs were divided into four types, including intergenic lncRNA, antisense lncRNA, sense lncRNA and intronic lncRNA, and the number and proportion of each type of lncRNAs were also calculated.

\subsection{Characteristic Comparison of $\operatorname{lnc} R N A$ s and $m R N A s$}

Expression of lncRNA was higher than that of messenger RNA, mRNA. However, the average length and open reading frame (ORF) length of mRNA were longer than those of lncRNA (Figure 3a-c). Moreover, less IncRNA were identified compared to mRNA based on the number of exons sequenced (Figure 3d).
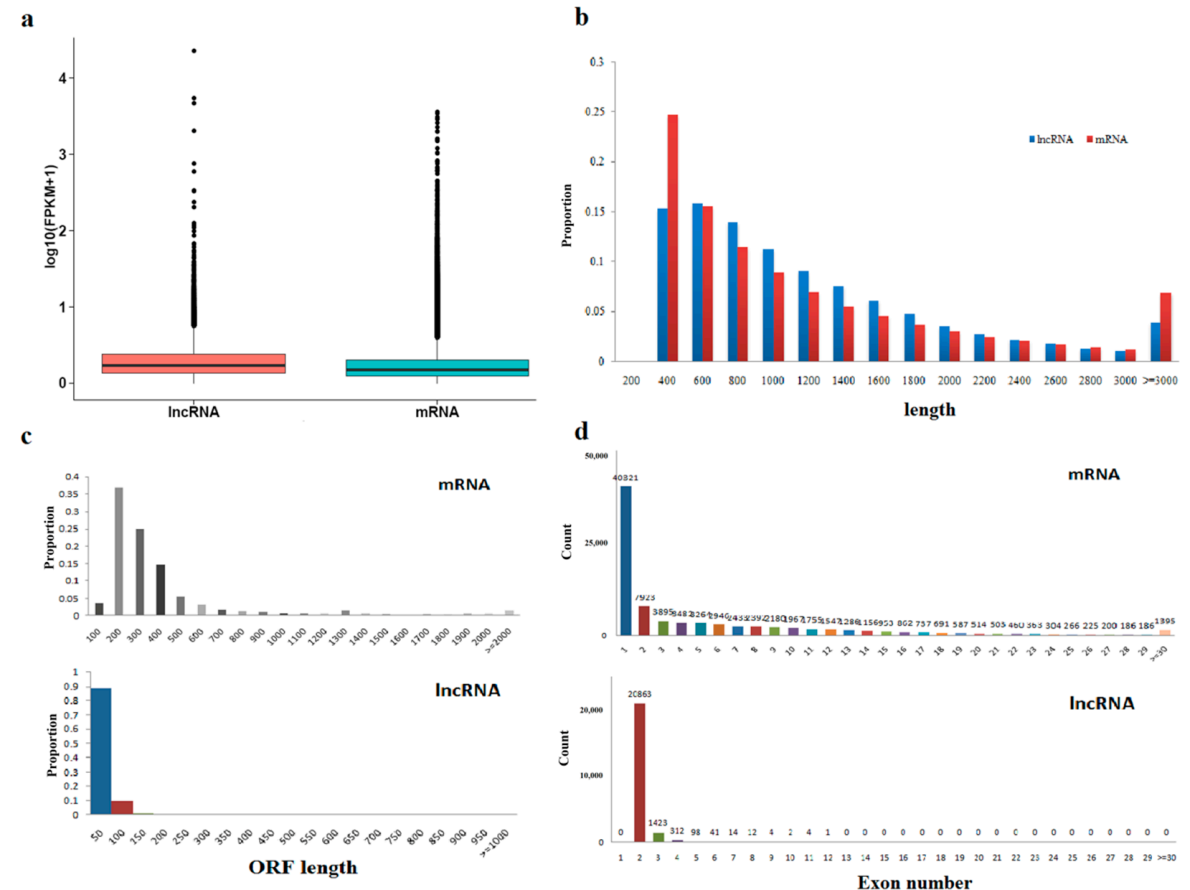

Figure 3. Comparison of the identified lncRNAs and mRNAs. (a) Expression level analysis of the mRNAs and lncRNAs. (b) The length distribution of lncRNAs and mRNAs. The abscissa represents length, and the ordinate is the number of RNA with length in this range. (c) Distribution of open reading frame lengths (ORF) in the mRNAs and lncRNAs. The abscissa represents ORF length, and the ordinate is exon numbers distributed in the range of RNA numbers. (d) Exon number distribution of lncRNAs and coding transcripts, the abscissa is exon numbers, and the ordinate is exon numbers distributed in the range of RNA numbers. 


\subsection{Differential Expression Analysis}

Fold Change $\geq 2.0$ and FDR $<0.05$ were used as screening criteria. A total of 2873 lncRNAs were differentially expressed between fresh and frozen-thawed sperm, among which 1477 lncRNAs were up-regulated and 1396 lncRNAs were down-regulated (Table S3, $p<0.05$ ). Results from cluster analysis of differentially expressed lncRNAs are presented as a heat map (Figure 4a). Meanwhile, 5226 significantly dysregulated mRNA transcripts were also identified, among which 3581 mRNAs were up-regulated and 1645 mRNAs were down-regulated in frozen-thawed sperm (Table S4, $p<0.05$ ). Results from cluster analysis of differentially expressed mRNAs are shown in a heat map (Figure $4 \mathrm{~b}$ ).
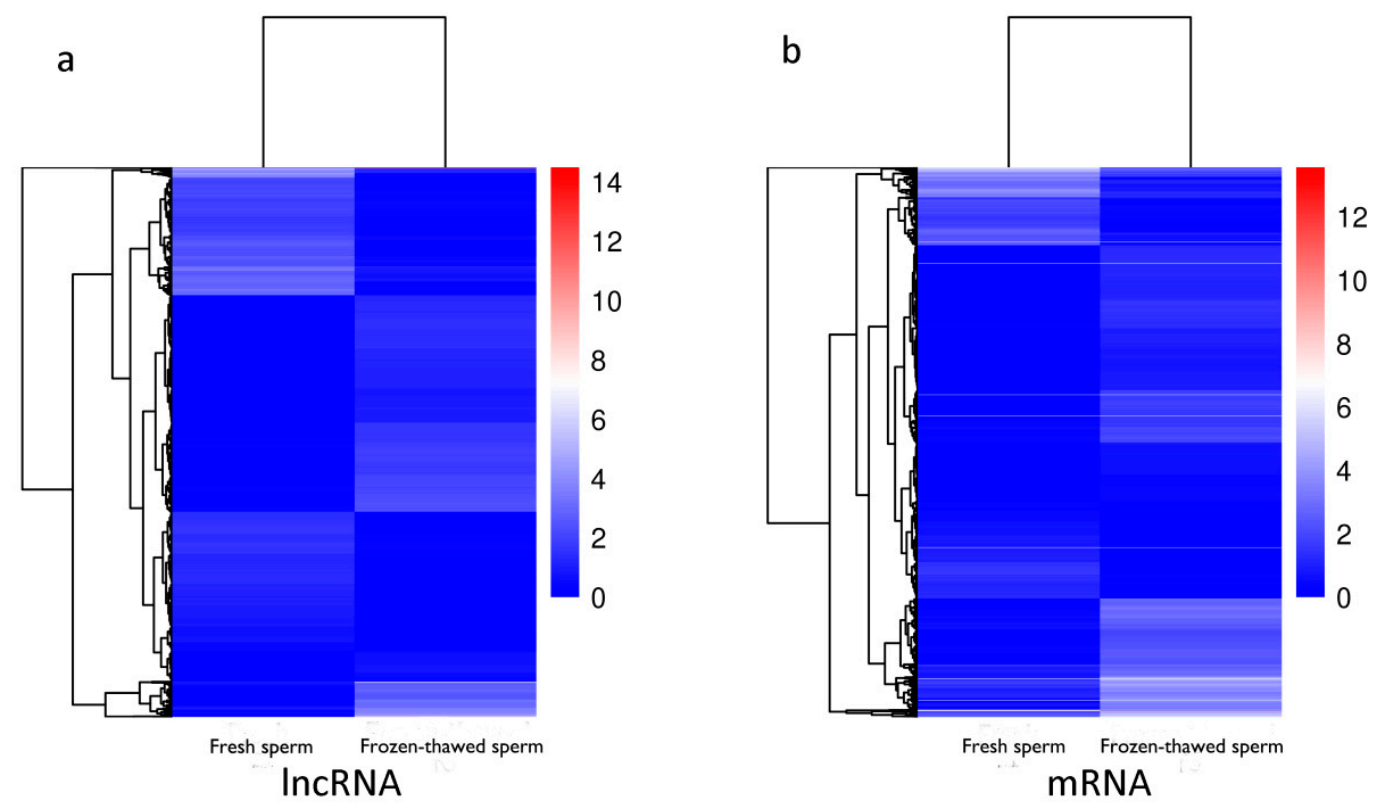

Figure 4. The heat maps of Cluster analysis of differentially expressed lncRNAs and mRNAs. (a) lncRNAs, (b) mRNAs. Red color indicated an increase in expression, and blue color indicated a decrease in expression.

\subsection{Target Genes Prediction of cis- and trans-LncRNAs}

LncRNAs can act on target genes, either in cis or in trans to co-expression with target genes. In order to explore the possible functions of differentially expressed lncRNAs, the target genes of IncRNA were predicated using the $c i s$ and trans model. The results showed that 7689 lncRNAs have the predicted cis target gene, and 1333 lncRNAs have the predicted trans target gene (Tables S5 and S6).

\section{8. qRT-PCR Validation}

Three lncRNAs and seven mRNAs that were differentially expressed between fresh and frozen-thawed sperm were selected for data validation of high throughput sequencing using qRT-PCR. Validation showed that all results were consistent with RNA-seq data, except for one mRNA that was not significantly differentially expressed $(p<0.05)$ (Figure 5$)$. The result indicated that the expression levels of all lncRNAs and mRNA were consistent with RNA-seq data, which confirmed the reliability of RNA-seq and laid a solid foundation for further exploration. 

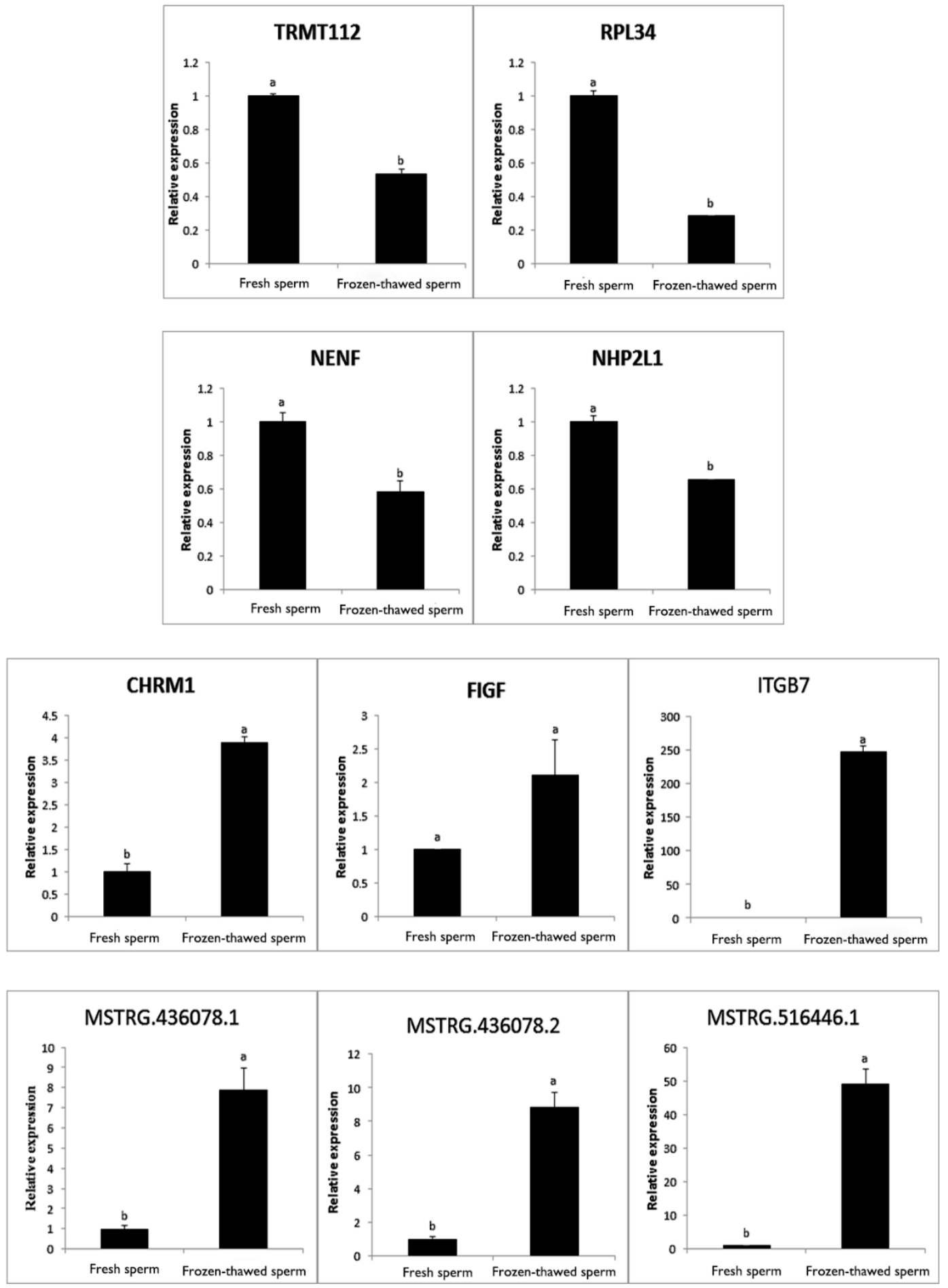

Figure 5. Validation of transcript expression by qRT-PCR. Glyceraldehyde-3-phosphate dehydrogenase $(\mathrm{GAPDH})$ gene was used as a housekeeping internal control. Transcript expression was quantified relative to the expression level of GAPDH using the comparative cycle threshold $\left(2^{-\Delta \Delta C t}\right)$ method. Different letter indicates $p<0.05$.

\subsection{Functional Enrichment Analysis of GO and KEGG}

GO analysis of predicted cis-lncRNA targets demonstrated 202 significantly enriched terms (Table S7, $p<0.05$ ). The top 5 terms were involved in single-organism process (GO: 0044699), olfactory receptor activity (GO: 0004984), detection of chemical stimulus involved in sensory perception of smell 
(GO: 0050911), G-protein coupled receptor activity (GO: 0004930), and signal transducer activity (GO: 0004930). Interestingly, the trans-membrane signaling receptor activity (GO: 0004888), membrane (GO: 0016020) and mitochondria (GO: 0005739) associated with sperm physiological and structural changes, were also significantly enriched in frozen-thawed sperm. KEGG analysis of the lncRNAs targets showed 10 enriched terms (Table S8, $p<0.05$ ). A number of target genes were annotated to the Olfactory transduction, apoptotic-associated pathway, including JAK-STAT (ko04142), Calcium (ko04020), and PI3K-Akt signaling pathway (ko04151).

Among the trans-lncRNA target genes, 233 GO terms were significantly enriched (Table S9, $p<0.05)$. The top 5 terms were involved in cell development (GO: 0048468), Ral GTPase activator activity (GO: 0005096), metanephric loop of Henle development (GO: 0072236), metanephric distal tubule development (GO: 0072235) and activation of Ral GTPase activity (GO: 0090630). Similar to the results of cis-lncRNA target genes, sperm membrane-related terms were significantly enriched, including membrane (GO: 0016020), integral component of membrane (GO: 0016021), and plasma membrane (GO: 0005886). Besides, 6 significantly enriched KEGG pathways were detected (Table S10, $p<0.05)$. Furthermore, 3 apoptotic-related pathways, calcium, p53 and PI3K-AKT signaling pathways were also involved.

GO and KEGG analyses of 5226 significantly dysregulated mRNAs showed that 365 GO terms (Table S11, $p<0.05$ ) and 14 significantly enriched pathways (Table S12, $p<0.05$ ) were highly enriched. Similar to the results of lncRNAs, a number of genes were annotated to the olfactory transduction, PI3K-AKT signaling pathway, JAK-STAT signaling pathway, Calcium signaling pathway, membrane and the integral component of membrane.

\subsection{Co-Expression of LncRNAs and $m R N A$}

The results of all lncRNAs and their target mRNAs were simultaneously and significantly differentially expressed in fresh and frozen-thawed sperms, which were summarized in Table S13.

\section{Discussion}

In this study, total RNA was extracted from motile and non-motile giant panda sperm after cryopreservation. Using the entire sperm population is representative of the natural transcript variation [32], and the increase of sperm apoptosis after cryopreservation is a part of sperm cryoinjury [33].

To date, this study is the first systematical lncRNA and mRNA profiling analysis of fresh and frozen-thawed sperms in the giant panda by high throughput sequencing. We acquired a total of 22,774 predicted lncRNAs and 32,322 mRNAs from giant panda sperms. Among 32,321 mRNAs, 13,186 novel genes and 19,136 known genes were identified. In general, the lncRNAs contained fewer exons, exhibited shorter overall length and average open reading frame length, and showed lower expression level than mRNAs, which was consistent with previous reports on goats, mice, pigs and other mammals [34-36]. The shared characteristics of lncRNAs in mammals implicate their important roles in the regulation, control, and guidance of sperm function.

Evidences have shown that sperm viability decreased by at least $50 \%$ because of cryodamage or cryoinjury during cryopreservation. Generally, sperm cryoinjury includes structural damage and functional changes. The process of cryopreservation could lead to increase in cell membrane fluidity, loss of plasma membrane integrity, impaired membrane protein function, decrease in sperm antioxidant activity, increase in oxidative stress and ROS levels, oxidative damage to DNA, mitochondrial damages, decrease in membrane potential, and altered phosphatidylserine reversion [37-40]. Among the adverse effects of cryopreservation, DNA oxidative damage, decrease in mitochondrial membrane potential and phosphatidylserine externalization are the main physiological characteristics of sperm apoptosis. In addition, it is believed that the cryopreservation process induces capacitation-like changes to sperm. Some of the similar changes observed between in vitro capacitation and cryo-capacitation include plasma membrane reorganization, increase in intracellular $\mathrm{Ca}^{2+}$ concentration and occurrence 
of PTP [41-43]. In this study, we identified 2873 lncRNAs and 5226 mRNAs that were significant differentially expressed between fresh and frozen-thawed sperm. The mRNAs targeted by these lncRNAs and the differentially expressed mRNA were mainly enriched in membrane-related terms (integral component of membrane and membrane) and responses to stimulus. Similar GO enrichment results were observed in GO analysis of differentially expressed proteins in rainbow trout frozen sperm [44] and differentially expressed miRNAs of porcine frozen sperm [18]. Moreover, these membrane-related terms could be associated with sperm cryodamage. In fact, KEGG analysis showed that mRNA, lncRNAs' cis-target genes and miRNAs' target genes were most widely distributed in the olfactory factor transduction pathway associated with membrane depolarization. The increase of membrane depolarized sperm isrelated to the apoptosis, and it is one of the reasons for the low fertilization rate of frozen thawed sperm [45]. It suggests that depolarization of sperm membrane associated with cAMP may be an important change in sperm membrane during cryopreservation. Furthermore, many lncRNA target genes or differentially expressed mRNAs were enriched in the PI3K-Akt, p53, Calcium, cAMP and MAPK signaling pathways. Among them, PI3K-Akt, p53, and Calcium signaling pathways were apoptosis-related pathways. Similar results from analysis of cryopreserved bull sperm also indicated target mRNAs of miRNAs and piRNAs were mainly involved in apoptotic-related pathways, especially in PI3K-Akt pathway [46]. In addition, cAMP and MAPK signaling pathways were capacitation-related pathways. These results support the conclusion that capacitation-like changes are induced during the process of sperm cryopreservation [47].

It is widely accepted that mature sperm cells contain RNA. These RNA molecules are thought to be remnants of transcription during spermatogenesis [10]. Gur and Breitbart [13] have demonstrated that protein transcription from nuclear genes occurs in sperm. It has also been shown that protein translation from mRNA transcripts takes place in ejaculated sperm during the final maturation steps prior to fertilization [14]. Furthermore, IncRNA also participates in the regulation of sperm capacitation [30], spermatogenesis [17] and definition of sperm parameters [19]. In the present study, both lncRNAs and their target genes were significantly dysregulated between fresh and frozen-thawed giant panda sperm (Table S11). Among them, 13 lncRNAs and 11 of their target mRNAs were found to be associated with sperm fertilization, spermatogenesis, and sperm capacitation or acrosome reaction (Table 1). In addition, 22 differentially expressed mRNAs were involved in sperm apoptosis (8 anti-apoptotic and 14 pro-apoptotic) (Table 2). Specifically, 4 mRNAs (RHOA, CDK5, MTA1, and CACNA1G) were involved in apoptosis and sperm function. In addition, lncRNA MSTRG.531884.1 and its 3 target mRNAs (CCL24, RHOBTB2, and CACNA1G) were differentially expressed and were associated with sperm apoptosis. Meanwhile, lncRNA MSTRG.655028.1 could regulate another 2 apoptotic-related differentially expressed mRNAs, MTA1 and CRIP2. A total of 4 mRNAs (FGFR4, SESN2, CRLF2 and CACNA1G) were annotated to apoptotic-related PI3K-Akt, p53, JAK-STAT, and Calcium signaling pathway, respectively. Therefore, we concluded that these differentially expressed lncRNAs and mRNAs may be involved in the regulatory roles of apoptosis during sperm cryopreservation. Generally, the function of lncRNAs is reflected by their effects on protein-coding genes. Many kinds of regulatory mechanisms between lncRNA and mRNA have been reported, including the guiding, combinational [48,49], protective [50], and competitive relationships that ultimately lead to inhibition of gene transcription, and promotion or inhibition of mRNA degradation, and finally, regulation of the expression level of mRNA. We speculated that lncRNA may also be involved in the regulation of cold response, freeze tolerance or cryoinjuries during sperm cryopreservation. However, the mechanism of regulation during sperm cryopreservation by interaction of differentially expressed lncRNAs and mRNAs is still unclear and warrants further investigation. 
Table 1. Function of lncRNAs and target mRNAs that were significantly differentially expressed between fresh and frozen-thawed giant panda sperm. Log2FC, $\log 2$ fold-change.

\begin{tabular}{lllll}
\hline IncRNA & log2FC & Target mRNA & log2FC & Description \\
\hline MSTRG.122368.1 & 3.14 & CDK5 & 2.76 & Regulating of sperm tail development [51] \\
\hline MSTRG.655028.1 & -2.86 & MTA1 & -3.33 & Crucial for spermatogenesis [52] \\
\hline MSTRG.332212.2 & 3.86 & RHOA & -3.02 & $\begin{array}{l}\text { Involved in capacitation and the acrosome } \\
\text { reaction [53] }\end{array}$ \\
\hline MSTRG.531884.1 & 3.93 & CACNA1G(Cav3.1) & 2.74 & Regulate male fertility in mice [54] \\
\hline MSTRG.264076.1 & 3.81 & SPAG8 & 3.18 & Cell division during spermatogenesis [55] \\
\hline MSTRG.480606.2 & 4.12 & SPEM1 & -2.53 & Spermatogenesis-essential proteins [56] \\
\hline MSTRG.408558.1 & 3.43 & TPST2 & 3.01 & Male infertility, sperm motility defects [57] \\
\hline MSTRG.369918.1 & 5.54 & PRSS37 & -3.28 & $\begin{array}{l}\text { Prss37 deletion markedly decreased fertilization rate } \\
\text { [58,59] }\end{array}$ \\
\hline MSTRG.169617.1 & 4.46 & CNGB1 & $\begin{array}{l}\text { Differentially represented between smokers and } \\
\text { non-smokers' sperm [60] }\end{array}$ \\
\hline MSTRG.597193.1 & 3.97 & CATSPER1 & -2.91 & $\begin{array}{l}\text { Involved in hyperactivation and essential for fertility } \\
\text { [61], functional failure of CatSper is sufficient to } \\
\text { compromise fertility of human sperm [62] }\end{array}$ \\
\hline MSTRG.651082.1 & 3.38 & OVGP1 & $\begin{array}{l}\text { Sustaining the sperm functions, include motile, } \\
\text { membrane intact, proportion of capacitated and } \\
\text { acrosome- reacted [63] }\end{array}$ \\
\hline MSTRG.651082.3 & -3.30 & $\begin{array}{l}\text { Essential for spermatogenesis in the mouse. Ccna1- } \\
\text { deficient spermatocytes arrest at late meiotic } \\
\text { prophase and undergo apoptosis [64] }\end{array}$ \\
\hline
\end{tabular}

Table 2. Apoptosis-related mRNAs and their corresponding lncRNAs that were significantly differentially expressed between fresh and frozen-thawed giant panda sperm. "-" means anti-apoptosis, "+" means pro-apoptosis. Log2FC: log2 fold-change.

\begin{tabular}{|c|c|c|c|c|c|}
\hline Gene Name & $\log 2 F C$ & Function & Ref. & lncRNA & Log2FC \\
\hline RHOBTB2 & 2.87 & + & [65] & MSTRG.531884.1 & 3.93 \\
\hline FGFR4 & 3.37 & + & [66] & MSTRG.628795.1 & 4.88 \\
\hline MTA1 & -3.33 & - & [67] & MSTRG.655028.1 & -2.86 \\
\hline PDCD2 & -2.72 & + & [68] & MSTRG.509816.1 & 4.02 \\
\hline TP53INP1 & -2.91 & + & [69] & MSTRG.561458.1 & -3.23 \\
\hline CRIP2 & -3.74 & + & [70] & MSTRG.655028.1 & -2.86 \\
\hline CACNA1G & 2.74 & + & [71] & MSTRG.531884.1 & 3.93 \\
\hline CCL24 & 5.23 & + & [72] & MSTRG.444753.1 & 4.88 \\
\hline BAG5 & -2.70 & - & [73] & MSTRG.263206.1 & 4.14 \\
\hline POU4F1 & 4.17 & + & {$[74,75]$} & MSTRG.306867.1 & -3.32 \\
\hline S100P & -2.52 & - & [76] & MSTRG.552283.1 & 3.52 \\
\hline CDK5 & 2.76 & + & [77] & MSTRG.122368.1 & 3.14 \\
\hline ETV4 & 2.60 & + & [78] & MSTRG.298973.1 & 4.73 \\
\hline \multirow{2}{*}{ PRPS2 } & \multirow{2}{*}{-2.66} & \multirow{2}{*}{-} & \multirow{2}{*}{ [79] } & MSTRG.101520.1 & -5.39 \\
\hline & & & & MSTRG.101521.1 & -4.27 \\
\hline SESN2 & 5.16 & + & [80] & MSTRG.33577.3 & 3.73 \\
\hline $\begin{array}{l}\text { TNFSF14 } \\
\text { (LIGHT) }\end{array}$ & 5.66 & + & [81] & MSTRG.609960.1 & -3.08 \\
\hline PRSS8 & 4.58 & + & [82] & MSTRG.493468.1 & 4.16 \\
\hline AHSA1 & -2.66 & - & [83] & MSTRG.555075.1 & 5.64 \\
\hline CYGB & 5.05 & - & [84] & MSTRG.301513.1 & -5.91 \\
\hline DDIT3 (CHOP) & -2.70 & + & [85] & MSTRG.141461.2 & 5.18 \\
\hline RHOA & -3.02 & - & [86] & MSTRG.332212.2 & 3.86 \\
\hline CRLF2 & 3.02 & - & [87] & MSTRG.343934.1 & -4.49 \\
\hline
\end{tabular}




\section{Materials and Methods}

\subsection{Animal Ethics Statement}

Semen collection and treatment were conducted according to the Regulations of the Administration of Affairs Concerning Experimental Animals (Ministry of Science and Technology, China, revised in June 2004) and approved by the Institutional Animal Care and Use Committee in the College of Animal Science and Technology, Sichuan Agricultural University, Sichuan, China, under permit No. DKYB20151013 (13 October 2015). Furthermore, all experimental protocols were approved by the College of Animal Science and Technology, Sichuan Agricultural University (NO. DKYB20151013, 13 October 2015).

\subsection{Sperm Collection and Cryopreservation}

Giant pandas $(n=5)$ that were disease-free and exhibited normal fertility, sexual maturity and normal semen quality were selected from the Bifengxia base of China Conservation and Research Center for the Giant Panda. Semen was collected using an electro-ejaculation method [88]. Then, semen was kept in $37^{\circ} \mathrm{C}$ water bath, and SQA-V semen quality analyzer (MES, Caesarea Industrial Park, Israel) was used to evaluate sperm quality parameters according to previous report [89]. The semen of 5 giant pandas was pooled then equally divided into two groups (Fresh sperm and cryopreserved sperm). The fresh semen was directly used for RNA extraction. Then, another aliquot of the semen was mixed in TEST-yolk buffer (TYB) with glycerol \& gentamicin frozen diluents (Irvine Scientific, Santa Ana, CA, USA) according to the manufacturer's instruction. Freezing protocols were performed according to the methods described in Spinder et al. [2]. In brief, sperms were diluted in TEST egg yolk buffer (Irvine Scientific) then combined with glycerol (final concentration of 5\% glycerol). Then, sperms were load into $0.25 \mathrm{~mL}$ straws and slowly cooled to $4{ }^{\circ} \mathrm{C}$ in a refrigerator over $4 \mathrm{~h}$ and then placed above liquid nitrogen (LN) to equilibrate at a rapid cryopreservation rate of $-40^{\circ} \mathrm{C} / \mathrm{min}$ (at $7.5 \mathrm{~cm}$ above $\mathrm{LN}$ for $1 \mathrm{~min}$ ) and $-100{ }^{\circ} \mathrm{C} / \mathrm{min}$ (at $2.5 \mathrm{~cm}$ above LN for $1 \mathrm{~min}$ ). Finally, all straws were submerged and storage in LN until use. During thawing, the straws were immersed into a $37^{\circ} \mathrm{C}$ water bath for $30 \mathrm{~s}$ and diluted with equal volume of HF10 (Ham's F10 medium with 5\% fetal calf serum and $25 \mathrm{mM}$ HEPES).

\subsection{Total RNA Extraction, Library Preparation, and Sequencing}

Before total RNA extraction, semen was washed three times to remove seminal plasma. The, sperm was treated with $0.5 \%$ of Triton X-100 to avoid somatic cells contamination according to previous study from our lab [90]. Then, total RNA was extracted from each sample according to the instruction manual of the TRIzol LS reagent (Invitrogen, Carlsbad, CA, USA). RNA degradation and contamination, especially DNA contamination, was monitored on $1.5 \%$ agarose gels. RNA concentration and purity were measured using the NanoDrop 2000 Spectrophotometer (Thermo Fisher Scientific, Wilmington, DE, USA). RNA integrity was assessed using the RNA Nano 6000 Assay Kit of the Agilent Bioanalyzer 2100 System (Agilent Technologies, Santa Clara, CA, USA). A total amount of $1.5 \mu \mathrm{g}$ RNA per sample was used as input material for rRNA removal using the Ribo-Zero rRNA Removal Kit (Epicentre, Madison, WI, USA).

Sequencing libraries were generated using NEB NextR Ultra Directional RNA Library Prep Kit for Illumina (NEB, Ipswich, MA, USA) following manufacturer's recommendations and index codes were added to attribute sequences to each sample. In order to select insert fragments of preferentially 150-200 bp in length, the library fragments were purified with AMPure XP Beads (Beckman Coulter, Beverly, MA, USA). Then PCR was performed with Phusion High-Fidelity DNA polymerase, Universal PCR primers and Index (X) Primer. At last, PCR products were purified (AMPure XP system) and library quality was assessed on the Agilent Bioanalyzer 2100 and qPCR, and then sequenced by Illumina Hiseq 2000 platform. 


\subsection{Quality Analysis, Mapping, and Transcriptome Assembly}

Clean data (clean reads) were obtained by removing reads that contained adapter, and ploy-N and of low quality from raw data. All the downstream analyses were based on clean data of high quality. Sequence alignment and subsequent analysis were performed using designated reference genome of giant panda (Ailuropoda melanoleuca) (available online: http:/ / ftp.ncbi.nlm.nih.gov/genomes/all/ GCF/000/004/335/GCF_000004335.2_AilMel_1.0). Then, clean reads were mapped to the giant panda (Ailuropoda melanoleuca) genome sequence with HISAT2 [91]. The mapped reads of each sample were assembled by StringTie [92].

\subsection{Identification and Expression Analysis of $\operatorname{lnc} R N A$ and $m R N A$}

The transcriptome was assembled based on the reads mapped to the reference genome. StringTie was used to calculate the read coverage of each transcript, and those with less than three read coverage were removed. Furthermore, tRNA, rRNA, snoRNA, snRNA, pre-miRNA, and pseudo-genes were also discarded. Then, the assembled transcripts were annotated using the gffcompare program. The qualified lncRNAs were immediately classified as known lncRNAs. The unknown transcripts were used to screen for putative lncRNAs. The unknown transcripts with lengths longer than $200 \mathrm{nt}$ and have more than two exons were selected as lncRNA candidates and subjected to further screening using CPC/CNCI/Pfam. The different types of lncRNAs, including lincRNA, intronic lncRNA, and anti-sense lncRNA, were selected using cuffcompare. Fragments per kilo-base of exon per million fragments mapped (FPKMs) of both lncRNAs and coding genes in each sample were calculate by StringTie (v1.3.1). Gene FPKMs were computed by summing the FPKMs of transcripts in each gene group based on the length of the fragments and read count mapped to that fragment.

Based on the selected reference genome sequence, the Cufflinks (v2.2.0) software was used to splice the Mapped Reads and compare with the original annotation information to find the original unannotated transcriptional area and explore the new transcriptional and new genes of the species, so as to supplement and improve the original annotation information of the original group. Filter out the short (less than 50 amino acid residues) of the encoded peptide chain or contain only a single exon sequence.

\subsection{Differential Expression Analysis}

Differential expression analysis of the two groups was performed using the DESeq $\mathrm{R}$ package (1.10.1). Genes with an adjusted $p<0.01$ and absolute value of $\log 2$ (Fold change) $>1$ were assigned as differentially expressed. Differential expression analysis of two samples without biological replicates was performed using the EBseq (2010) R package, and $q$-value $<0.01 \& \mid \log 2$ (fold change) $\mid>1$ were set as the threshold for significant differential expression.

\subsection{Target Gene Prediction}

In this study, cis- and trans-analyses were used to predict the target genes of lncRNAs. Briefly, the coding genes that were $100 \mathrm{~K}$ upstream and downstream of lncRNAs were searched as cis results. LncTar target gene prediction tools were used to predict trans-target genes of lncRNA.

\section{8. qRT-PCR Validation}

qRT-PCR was performed using SYBR Premix Ex Taq II (TaRaKa Biotech, Dalian, China) on a StepOnePlus real-time PCR system (Applied BioSystems, Foster City, CA, USA) using an annealing temperature of $60{ }^{\circ} \mathrm{C}$ according to our laboratory's protocols. The specific quantitative primers for 10 transcripts were listed in Table 3. In addition, GAPDH was used as an endogenous control. The conditions were as follows: $95^{\circ} \mathrm{C}$ for $30 \mathrm{~s}$, followed by 40 cycles $\left(95^{\circ} \mathrm{C}\right.$ for $5 \mathrm{~s}$ and $60{ }^{\circ} \mathrm{C}$ for $30 \mathrm{~s}$; next, $95^{\circ} \mathrm{C}$ for $10 \mathrm{~s}, 60^{\circ} \mathrm{C}$ for $2 \mathrm{~s}$; Finally, 60 to $95^{\circ} \mathrm{C}$, increment $0.5^{\circ} \mathrm{C}$ for $2 \mathrm{~s}$ ). Each experiment was performed intriplicate. 
Table 3. Primers used for qRT-PCR and validation.

\begin{tabular}{|c|c|c|}
\hline Gene Name & Primer Sequence $\left(5^{\prime}-3^{\prime}\right)$ & Amplicon (bp) \\
\hline ITGB7 & $\begin{array}{l}\text { F: AGGTCTCATCCCCCGAGAAG } \\
\text { R: CGTACACAGGGTTCAAAGGC }\end{array}$ & 168 \\
\hline MSTRG.436078.1 & $\begin{array}{l}\text { F: CAGGCTTCCTCCTCTCTCCA } \\
\text { R: CCACCAGATCTCAAGGACAGC }\end{array}$ & 143 \\
\hline MSTRG.436078.2 & $\begin{array}{l}\text { F: GCCTGTCTCATTGCTCAAGGT } \\
\text { R: GGACTATTCTGGTAGCTGTGTCCA }\end{array}$ & 114 \\
\hline CHRM1 & $\begin{array}{l}\text { F: GCAAGTGGCTTTCATTGGGA } \\
\text { R: CAGGCTGAGCAGGAAGTAGT }\end{array}$ & 133 \\
\hline MSTRG.516446.1 & $\begin{array}{l}\text { F: GGAGAATTACGGTGGGATGAC } \\
\text { R: AAGAAAACACTAACGCAGAAAGG }\end{array}$ & 149 \\
\hline FIGF(VEGFD) & $\begin{array}{l}\text { F: AAGGAGAAGAGGGCTGCCTA } \\
\text { R: GACAGCAACTTGGCAAAGCA }\end{array}$ & 117 \\
\hline NENF & $\begin{array}{l}\text { F: TGGCAGTGAAAGGAGTGGTGTT } \\
\text { R: CCCGTAGTGTCATGGGTGAGGT }\end{array}$ & 151 \\
\hline RPL34 & $\begin{array}{l}\text { F: AAACTAGGCTGTCCCGAACC } \\
\text { R: AGCACGAACTCCTCGAAGTC }\end{array}$ & 119 \\
\hline NHP2L1 & $\begin{array}{l}\text { F: CGGAAAGGAGCCAATGAAG } \\
\text { R: CAGAACAGGCGATGACAGG }\end{array}$ & 205 \\
\hline TRMT112 & $\begin{array}{l}\text { F: TGGCGCGTATGATACCCAAG } \\
\text { R: GCGACTGATGGGGAACAGAT }\end{array}$ & 209 \\
\hline
\end{tabular}

\subsection{GO and KEGG Enrichment Analyses}

GO enrichment analysis was applied to target genes of lncRNAs using the GOseqR package. In addition, the differentially expressed protein coding genes were also analyzed using GO. The enrichment of lncRNA target genes or differentially expressed protein-coding genes in KEGG pathways were analyzed by the KOBAS (v3.0, Center for Bioinformatics, Peking University, China) software.

\subsection{Statistical Analysis}

The statistical differences were analyzed using the SPSS (version 20.0, IBM, Chicago, IL, USA) by independent-samples $t$-test. All data were shown as the means \pm SEM. $p$ values $<0.05$ were regarded as statistically significant.

\section{Conclusions}

In conclusion, our work is the first to provide the expression profiles of lncRNAs, and mRNAs in fresh and frozen-thawed giant panda sperm. These differentially expressed lncRNAs and mRNAs are found to be involved in the function of sperm membrane, metabolism, capacitation, apoptosis, and definition of post-thawed sperm quality parameters. Our findings provide valuable insights for future investigation of the mechanism of sperm cryoinjury and freeze tolerance during cryopreservation.

Supplementary Materials: Supplementary materials can be found at http:/ / www.mdpi.com/1422-0067/19/10/ 3066/s1.

Author Contributions: The manuscript was written by M.-X.R., C.-J.Z. designed and revised the manuscript. M.X.R., Y.L., Y.Z., K.L., Y.N.R., Y.M.Z., K.W., C.-D.W., Y.H., B.L. and H.-M.Z. carried out the experiments and collected semen. M.Z., G.-B.Z. and I.H.Q. revised and edited the manuscript. All authors reviewed and revised the manuscript.

Funding: This work was supported by grants from National Natural Science Foundation of China (No. 31570533 and No. 31872356).

Acknowledgments: We give special thanks to China Conservation for Giant Panda Breeding for semen collection.

Conflicts of Interest: The authors declare no conflict of interest. 


\section{References}

1. Feng, W.H. The artificial breeding and protecrion of giant panda. Explor. Nat. 1992, 11, $27-32$.

2. Spindler, R.E.; Huang, Y.; Howard, J.G.; Wang, P.; Zhang, H.; Zhang, G.; Wildt, D.E. Acrosomal integrity and capacitation are not influenced by sperm cryopreservation in the giant panda. Reproduction 2004, 127, 547-556. [CrossRef] [PubMed]

3. Feng, W.H.; Wang, P.Y.; Wang, C.R. Study on semen character of giant panda I. Observation of semen quality. Acta Theriol. Sinica 1991, 11, 1-8.

4. Huang, Y.; Li, D.; Zhang, H.; Du, J.; Zhang, G.; Wang, P.; Howard, J.; Spindler, R. Studies on spermatozoa in giant pandas. Chin. J. Vet. Med. 2001, 37, 9-11.

5. Hou, R.; Wang, J.S.; Zhang, H.M.; Lan, J.C.; Wang, C.D.; Yu, J.Q.; Huang, X.M. Development and application of new method for in giant panda semen cryopreservation. Chin. J. Vet. Sci. 2005, 25, 320-322.

6. Zhou, Y.M.; Wu, D.; Tang, C.X.; Qu, C.M. Effects of adding vitamin b12,BSA and heparin in medium for frozen sperm quality of giant panda. Sichuan J. Zool. 2007, 26, 669-671.

7. Huang, Y.; Li, D.S.; Zhang, H.M.; Du, J.; Zhang, G.Q.; Wang, P.Y.; Howard, J.; Spindler, R. Study for freezing semen of giant pandas. Chin. J. Zool. 2001, 36, 25-29.

8. Huang, Y.; Wang, Y.P.; Spindler Rebecca, E.; JoGayle, H.; Zhang, H.; David, E.W. Study on the influence of post-thaw motility on giant panda cryopreserved sperm by thawing rate and pentyoxyfilline in vitro. Acta Theriol. Sin. 2004, 24, 286-292.

9. Santiago-Moreno, J.; Esteso, M.C.; Pradiee, J.; Castano, C.; Toledano-Diaz, A.; O’Brien, E.; Lopez-Sebastian, A.; Martinez-Nevado, E.; Delclaux, M.; Fernandez-Moran, J.; et al. Giant panda (Ailuropoda melanoleuca) sperm morphometry and function after repeated freezing and thawing. Andrologia 2016, 48, 470-474. [CrossRef] [PubMed]

10. Pantano, L.; Jodar, M.; Bak, M.; Ballesca, J.L.; Tommerup, N.; Oliva, R.; Vavouri, T. The small RNA content of human sperm reveals pseudogene-derived piRNAs complementary to protein-coding genes. RNA 2015, 21, 1085-1095. [CrossRef] [PubMed]

11. NAZ, R.K. Effect of actinomycin d and cycloheximide on human sperm function. Arch. Androl. 1998, 41, 135-142. [CrossRef] [PubMed]

12. Sciamanna, I.; Barberi, L.; Martire, A.; Pittoggi, C.; Beraldi, R.; Giordano, R.; Rosa Magnano, A.; Hogdson, C.; Spadafora, C. Sperm endogenous reverse transcriptase as mediator of new genetic information. Biochem. Biophys. Res. Commun. 2003, 312, 1039-1046. [CrossRef] [PubMed]

13. Gur, Y.; Breitbart, H. Mammalian sperm translate nuclear-encoded proteins by mitochondrial-type ribosomes. Genes Dev. 2006, 20, 411-416. [CrossRef] [PubMed]

14. Gur, Y.; Breitbart, H. Protein synthesis in sperm: Dialog between mitochondria and cytoplasm. Mol. Cell. Endocrinol. 2008, 282, 45-55. [CrossRef] [PubMed]

15. Zhang, Z.; Zhou, X.; Li, H.X.; Cui, Q.W.; Yu, J.; Wang, G.L. Delivery of CatSper2 siRNA into rat sperms by electroporation repressed $\mathrm{Ca}^{2+}$ influx during sperm hyperactivation. Agric. Sci. China 2011, 10, 1958-1967. [CrossRef]

16. Yu, J.; Jiang, X.Q.; Zhou, S.; Wang, G.I. RNA interference-mediated downregulation of $s A C$ gene inhibits sperm hyperactivation in male rats (Rattus norvegicus). J. Integr. Agric. 2014, 13, 394-401. [CrossRef]

17. Wichman, L.; Somasundaram, S.; Breindel, C.; Valerio, D.M.; McCarrey, J.R.; Hodges, C.A.; Khalil, A.M. Dynamic expression of long noncoding RNAs reveals their potential roles in spermatogenesis and fertility. Biol. Reprod. 2017, 97, 313-323. [CrossRef] [PubMed]

18. Zhang, Y.; Dai, D.; Chang, Y.; Li, Y.; Zhang, M.; Zhou, G.; Peng, Z.; Zeng, C. Cryopreservation of boar sperm induces differential microRNAs expression. Cryobiology 2017, 76, 24-33. [CrossRef] [PubMed]

19. An, T.; Fan, H.; Liu, Y.F.; Pan, Y.Y.; Liu, Y.K.; Mo, F.F.; Gu, Y.J.; Sun, Y.L.; Zhao, D.D.; Yu, N.; et al. The difference in expression of long noncoding RNAs in rat semen induced by high-fat diet was associated with metabolic pathways. Peer J. 2017, 5, e3518. [CrossRef] [PubMed]

20. Kornienko, A.E.; Guenzl, P.M.; Barlow, D.P.; Pauler, F.M. Gene regulation by the act of long non-coding RNA transcription. BMC Biol. 2013, 11, 1-14. [CrossRef] [PubMed]

21. Wang, K.C.; Yang, Y.W.; Liu, B.; Sanyal, A.; Corces-Zimmerman, R.; Chen, Y.; Lajoie, B.R.; Protacio, A.; Flynn, R.A.; Gupta, R.A.; et al. A long noncoding RNA maintains active chromatin to coordinate homeotic gene expression. Nature 2011, 472, 120-124. [CrossRef] [PubMed] 
22. Loewer, S.; Cabili, M.N.; Guttman, M.; Loh, Y.H.; Thomas, K.; Park, I.H.; Garber, M.; Curran, M.; Onder, T.; Agarwal, S.; et al. Large intergenic non-coding RNA-RoR modulates reprogramming of human induced pluripotent stem cells. Nat. Genet. 2010, 42, 1113-1117. [CrossRef] [PubMed]

23. Khalil, A.M.; Guttman, M.; Huarte, M.; Garber, M.; Raj, A.; Morales, D.R.; Thomas, K.; Presser, A.; Bernstein, B.E.; van Oudenaarden, A.; et al. Many human large intergenic noncoding RNAs associate with chromatin-modifying complexes and affect gene expression. Proc. Natl. Acad. Sci. USA 2009, 106, 11667-11672. [CrossRef] [PubMed]

24. Hung, T.; Wang, Y.L.; Lin, M.F.; Koegel, A.K.; Kotake, Y.; Grant, G.D.; Horlings, H.M.; Shah, N.; Umbricht, C.; Wang, P.; et al. Extensive and coordinated transcription of noncoding RNAs within cell-cycle promoters. Nat. Genet. 2011, 43, 621-629. [CrossRef] [PubMed]

25. Guttman, M.; Donaghey, J.; Carey, B.W.; Garber, M.; Grenier, J.K.; Munson, G.; Young, G.; Lucas, A.B.; Ach, R.; Bruhn, L.; et al. LincRNAs act in the circuitry controlling pluripotency and differentiation. Nature 2011, 477, 295-300. [CrossRef] [PubMed]

26. Bao, J.; Wu, J.; Schuster, A.S.; Hennig, G.W.; Yan, W. Expression profiling reveals developmentally regulated IncRNA repertoire in the mouse male germline. Biol. Reprod. 2013, 89, 1-17. [CrossRef] [PubMed]

27. Li, L.; Wang, M.; Wang, M.; Wu, X.; Geng, L.; Xue, Y.; Wei, X.; Jia, Y.; Wu, X. A long non-coding RNA interacts with Gfra1 and maintains survival of mouse spermatogonial stem cells. Cell Death Dis. 2016, 7, e2140. [CrossRef] [PubMed]

28. Anguera, M.C.; Ma, W.; Clift, D.; Namekawa, S.; Kelleher, R.J., III; Lee, J.T. Tsx produces a long noncoding RNA and has general functions in the germline, stem cells, and brain. PLoS Genet. 2011, 7, e1002248. [CrossRef]

29. Zhang, Z.L.; Li, X.K.; Zhang, P.; Wang, J.; Zhu, D.D.; Chen, X.P.; Ye, L.H. Low long non-coding RNA hotair expression is associated with down-regulation of nrf2 in the spermatozoa of patients with asthenozoospermia or oligoasthenozoospermia. Int. J. Clin. Exp. Pathol. 2015, 8, 14198-14205. [PubMed]

30. Ni, M.J.; Hu, Z.H.; Liu, Q.; Liu, M.F.; Lu, M.H.; Zhang, J.S.; Zhang, L.; Zhang, Y.L. Identification and characterization of a novel non-coding RNA involved in sperm maturation. PLoS ONE 2011, 6, e26053. [CrossRef] [PubMed]

31. Jiang, G.J.; Zhang, T.; An, T.; Zhao, D.D.; Yang, X.Y.; Zhang, D.W.; Zhang, Y.; Mu, Q.Q.; Yu, N.; Ma, X.S.; et al. Differential expression of long noncoding RNAs between sperm samples from diabetic and non-diabetic mice. PLoS ONE 2016, 11, e0154028. [CrossRef] [PubMed]

32. Card, C.J.; Anderson, E.J.; Zamberlan, S.; Krieger, K.E.; Kaproth, M.; Sartini, B.L. Cryopreserved bovine spermatozoal transcript profile as revealed by high-throughput ribonucleic acid sequencing. Biol. Reprod. 2013, 88. [CrossRef] [PubMed]

33. Said, T.M.; Gaglani, A.; Agarwal, A. Implication of apoptosis in sperm cryoinjury. Reprod. Biomed. Online 2010, 21, 456-462. [CrossRef] [PubMed]

34. Gao, X.; Ye, J.; Yang, C.; Zhang, K.; Li, X.; Luo, L.; Ding, J.; Li, Y.; Cao, H.; Ling, Y.; et al. Screening and evaluating of long noncoding RNAs in the puberty of goats. BMC Genom. 2017, 18, 164. [CrossRef] [PubMed]

35. Zhang, S.; Qin, C.; Cao, G.Q.; Xin, W.F.; Feng, C.Q.; Zhang, W.S. Systematic analysis of long noncoding RNAs in the senescence-accelerated mouse prone 8 brain using RNA sequencing. Mol. Ther. Nucleic Acids 2016, 5, e343. [CrossRef] [PubMed]

36. Wang, Y.; Xue, S.; Liu, X.; Liu, H.; Hu, T.; Qiu, X.; Zhang, J.; Lei, M. Analyses of long non-coding RNA and mRNA profiling using RNA sequencing during the pre-implantation phases in pig endometrium. Sci. Rep. 2016, 6. [CrossRef] [PubMed]

37. Cerolini, S.; Maldjian, A.; Pizzi, F.; Gliozzi, T.M. Changes in sperm quality and lipid composition during cryopreservation of boar semen. Reproduction 2001, 121, 395-401. [CrossRef] [PubMed]

38. Saleh, R.A.; Agarwal, A. Oxidative stress and male infertility: From research bench to clinical practice. J. Androl. 2002, 23, 737-752. [PubMed]

39. Paasch, U.; Sharma, R.K.; Gupta, A.K.; Grunewald, S.; Mascha, E.J.; Thomas, A.J., Jr.; Glander, H.J.; Agarwal, A. Cryopreservation and thawing is associated with varying extent of activation of apoptotic machinery in subsets of ejaculated human spermatozoa. Biol. Reprod. 2004, 71, 1828-1837. [CrossRef] [PubMed]

40. Eilish, T.; Donnelly, N.M.; Sheena, E.M.; Lewis, S.E. Cryopreservation of human semen and prepared sperm: Effects on motility parameters and DNA integrity. Fertil. Steril. 2001, 76, 892-900. 
41. Kumar, R.; Atreja, S.K. Effect of incorporation of additives in tris-based egg yolk extender on buffalo (Bubalus bubalis) sperm tyrosine phosphorylation during cryopreservation. Reprod. Domest. Anim. 2012, 47, 485-490. [CrossRef] [PubMed]

42. Pommer, A.C.; Meyers, S.A. Tyrosine phosphorylation is an indicator of capacitation status in fresh and cryopreserved stallion spermatozoa. Theriogenology 2002, 58, 351-354.

43. Singh, V.K.; Atreja, S.K.; Kumar, R.; Chhillar, S.; Singh, A.K. Assessment of intracellular ca ${ }^{2+}$, camp and 1,2-diacylglycerol in cryopreserved buffalo (Bubalus bubalis) spermatozoa on supplementation of taurine and trehalose in the extender. Reprod. Domest. Anim. 2012, 47, 584-590. [CrossRef] [PubMed]

44. Nynca, J.; Arnold, G.J.; Frohlich, T.; Ciereszko, A. Cryopreservation-induced alterations in protein composition of rainbow trout semen. Proteomics 2015, 15, 2643-2654. [CrossRef] [PubMed]

45. Ortega Ferrusola, C.; Anel-Lopez, L.; Ortiz-Rodriguez, J.M.; Martin Munoz, P.; Alvarez, M.; de Paz, P.; Masot, J.; Redondo, E.; da Silva, C.B.; Morrell, J.M.; et al. Stallion spermatozoa surviving freezing and thawing experience membrane depolarization and increased intracellular na. Andrology 2017, 5, 1174-1182. [CrossRef] [PubMed]

46. Capra, E.; Turri, F.; Lazzari, B.; Cremonesi, P.; Gliozzi, T.M.; Fojadelli, I.; Stella, A.; Pizzi, F. Small RNA sequencing of cryopreserved semen from single bull revealed altered miRNAs and piRNAs expression between high- and low-motile sperm populations. BMC Genom. 2017, 18. [CrossRef] [PubMed]

47. Naresh, S.; Atreja, S.K. The protein tyrosine phosphorylation during in vitro capacitation and cryopreservation of mammalian spermatozoa. Cryobiology 2015, 70, 211-216. [CrossRef] [PubMed]

48. Gong, C.; Maquat, L.E. LncRNAs transactivate STAU1-mediated mRNA decay by duplexing with $3^{\prime}$ UTRs via Alu elements. Nature 2011, 470, 284-288. [CrossRef] [PubMed]

49. Nagano, T.; Mitchell, J.A.; Sanz, L.A.; Pauler, F.M.; Ferguson-Smith, A.C.; Feil, R.; Fraser, P. The air noncoding RNA epigenetically silences transcription by targeting G9a to chromatin. Science 2008, 322, 1717-1720. [CrossRef] [PubMed]

50. Yuan, J.H.; Liu, X.N.; Wang, T.T.; Pan, W.; Tao, Q.F.; Zhou, W.P.; Wang, F.; Sun, S.H. The MBNL3 splicing factor promotes hepatocellular carcinoma by increasing pxn expression through the alternative splicing of lncRNA-PXN-AS1. Nat. Cell Biol. 2017, 19, 820-832. [CrossRef] [PubMed]

51. Rosales, J.L.; Lee, B.C.; Modarressi, M.; Sarker, K.P.; Lee, K.Y.; Jeong, Y.G.; Oko, R.; Lee, K.Y. Outer dense fibers serve as a functional target for cdk5.P35 in the developing sperm tail. J. Biol. Chem. 2004, 279, 1224-1232. [CrossRef] [PubMed]

52. Li, W.; Zhang, J.; Liu, X.; Xu, R.; Zhang, Y. Correlation of appearance of metastasis-associated protein1 (Mta1) with spermatogenesis in developing mouse testis. Cell Tissue Res. 2007, 329, 351-362. [CrossRef] [PubMed]

53. Fiedler, S.E.; Bajpai, M.; Carr, D.W. Identification and characterization of RHOA-interacting proteins in bovine spermatozoa. Biol. Reprod. 2008, 78, 184-192. [CrossRef] [PubMed]

54. Tao, J.; Zhang, Y.; Li, S.; Sun, W.; Soong, T.W. Tyrosine kinase-independent inhibition by genistein on spermatogenic T-type calcium channels attenuates mouse sperm motility and acrosome reaction. Cell Calcium 2009, 45, 133-143. [CrossRef] [PubMed]

55. Wu, H.; Chen, Y.; Miao, S.; Zhang, C.; Zong, S.; Koide, S.S.; Wang, L. Sperm associated antigen 8 (SPAG8), a novel regulator of activator of crem in testis during spermatogenesis. FEBS Lett. 2010, 584, 2807-2815. [CrossRef] [PubMed]

56. Bao, J.; Zhang, J.; Zheng, H.; Xu, C.; Yan, W. Ubqln1 interacts with spem1 and participates in spermiogenesis. Mol. Cell. Endocrinol. 2010, 327, 89-97. [CrossRef] [PubMed]

57. Marcello, M.R.; Jia, W.; Leary, J.A.; Moore, K.L.; Evans, J.P. Lack of tyrosylprotein sulfotransferase-2 activity results in altered sperm-egg interactions and loss of adam3 and adam6 in epididymal sperm. J. Biol. Chem. 2011, 286, 13060-13070. [CrossRef] [PubMed]

58. Liu, J.; Shen, C.; Fan, W.; Chen, Y.; Zhang, A.; Feng, Y.; Li, Z.; Kuang, Y.; Wang, Z. Low levels of PRSS37 protein in sperm are associated with many cases of unexplained male infertility. Acta Biochim. Biophys. Sin. 2016, 48, 1058-1065. [CrossRef] [PubMed]

59. Shen, C.; Kuang, Y.; Liu, J.; Feng, J.; Chen, X.; Wu, W.; Chi, J.; Tang, L.; Wang, Y.; Fei, J.; et al. PRSS37 is required for male fertility in the mouse. Biol. Reprod. 2013, 88. [CrossRef] [PubMed] 
60. Metzler-Guillemain, C.; Victorero, G.; Lepoivre, C.; Bergon, A.; Yammine, M.; Perrin, J.; Sari-Minodier, I.; Boulanger, N.; Rihet, P.; Nguyen, C. Sperm mRNAs and microRNAs as candidate markers for the impact of toxicants on human spermatogenesis: An application to tobacco smoking. Syst. Biol. Reprod. Med. 2015, 61, 139-149. [CrossRef] [PubMed]

61. Ernesto, J.I.; Weigel Munoz, M.; Battistone, M.A.; Vasen, G.; Martinez-Lopez, P.; Orta, G.; Figueiras-Fierro, D.; de la Vega-Beltran, J.L.; Moreno, I.A.; Guidobaldi, H.A.; et al. CRISP1 as a novel CatSper regulator that modulates sperm motility and orientation during fertilization. J. Cell Biol. 2015, 210, 1213-1224. [CrossRef] [PubMed]

62. Williams, H.L.; Mansell, S.; Alasmari, W.; Brown, S.G.; Wilson, S.M.; Sutton, K.A.; Miller, M.R.; Lishko, P.V.; Barratt, C.L.; Publicover, S.J.; et al. Specific loss of CatSper function is sufficient to compromise fertilizing capacity of human spermatozoa. Hum. Reprod. 2015, 30, 2737-2746. [CrossRef] [PubMed]

63. Choudhary, S.; Kumaresan, A.; Kumar, M.; Chhillar, S.; Malik, H.; Kumar, S.; Kaushik, J.K.; Datta, T.K.; Mohanty, A.K. Effect of recombinant and native buffalo OVGP1 on sperm functions and in vitro embryo development: A. comparative study. J. Anim. Sci. Biotechnol. 2017, 8. [CrossRef] [PubMed]

64. Panigrahi, S.K.; Manterola, M.; Wolgemuth, D.J. Meiotic failure in cyclin A1-deficient mouse spermatocytes triggers apoptosis through intrinsic and extrinsic signaling pathways and 14-3-3 proteins. PLoS ONE 2017, 12, e0173926. [CrossRef] [PubMed]

65. Freeman, S.N.; Ma, Y.; Cress, W.D. RhoBTB2 (DBC2) is a mitotic E2F1 target gene with a novel role in apoptosis. J. Biol. Chem. 2008, 283, 2353-2362. [CrossRef] [PubMed]

66. Ho, H.K.; Pok, S.; Streit, S.; Ruhe, J.E.; Hart, S.; Lim, K.S.; Loo, H.L.; Aung, M.O.; Lim, S.G.; Ullrich, A. Fibroblast growth factor receptor 4 regulates proliferation, anti-apoptosis and alpha-fetoprotein secretion during hepatocellular carcinoma progression and represents a potential target for therapeutic intervention. J. Hepatol. 2009, 50, 118-127. [CrossRef] [PubMed]

67. Kai, L.; Samuel, S.K.; Levenson, A.S. Resveratrol enhances p53 acetylation and apoptosis in prostate cancer by inhibiting MTA1/NuRD complex. Int. J. Cancer 2010, 126, 1538-1548. [CrossRef] [PubMed]

68. Baron, B.W.; Hyjek, E.; Gladstone, B.; Thirman, M.J.; Baron, J.M. PDCD2, a protein whose expression is repressed by BCL6, induces apoptosis in human cells by activation of the caspase cascade. Blood Cell. Mol. Dis. 2010, 45, 169-175. [CrossRef] [PubMed]

69. N'Guessan, P.; Pouyet, L.; Gosset, G.; Hamlaoui, S.; Seillier, M.; Cano, C.E.; Seux, M.; Stocker, P.; Culcasi, M.; Iovanna, J.L.; et al. Absence of tumor suppressor tumor protein 53-induced nuclear protein 1 (TP53INP1) sensitizes mouse thymocytes and embryonic fibroblasts to redox-driven apoptosis. Antioxid. Redox Signal. 2011, 15, 1639-1653. [CrossRef] [PubMed]

70. Lo, P.H.; Ko, J.M.; Yu, Z.Y.; Law, S.; Wang, L.D.; Li, J.L.; Srivastava, G.; Tsao, S.W.; Stanbridge, E.J.; Lung, M.L. The lim domain protein, CRIP2, promotes apoptosis in esophageal squamous cell carcinoma. Cancer Lett. 2012, 316, 39-45. [CrossRef] [PubMed]

71. Ohkubo, T. T-type voltage-activated calcium channel Cav3.1, but not Cav3.2, is involved in the inhibition of proliferation and apoptosis in MCF-7 human breast cancer cells. Int. J. Oncol. 2012, 41, 267-275. [CrossRef] [PubMed]

72. Li, H.; Huang, Y.H.; Li, M.Q.; Meng, Y.H.; Chen, X.; Shao, J.; Tang, C.L.; Du, M.R.; Jin, L.P.; Li, D.J.; et al. Trophoblasts-derived chemokine CCL24 promotes the roliferation, growth and apoptosis of decidual stromal cells in human early pregnancy. Int. J. Clin. Exp. Pathol. 2013, 6, 1028-1037. [PubMed]

73. Bruchmann, A.; Roller, C.; Walther, T.V.; Schäfer, G.; Lehmusvaara, S.; Visakorpi, T.; Klocker, H.; Cato, A.C.; Maddalo, D. Bcl-2 associated athanogene 5 (Bag5) is overexpressed in prostate cancer and inhibits ER-stress induced apoptosis. BMC Cancer 2013, 13. [CrossRef]

74. Maskell, L.J.; Qamar, K.; Babakr, A.A.; Hawkins, T.A.; Heads, R.J.; Budhram-Mahadeo, V.S. Essential but partially redundant roles for POU4F1/Brn-3a and POU4F2/Brn-3b transcription factors in the developing heart. Cell Death. Dis. 2017, 8, e2861. [CrossRef] [PubMed]

75. Budhram-Mahadeo, V.; Fujita, R.; Bitsi, S.; Sicard, P.; Heads, R. Co-expression of POU4F2/Brn-3b with p53 may be important for controlling expression of pro-apoptotic genes in cardiomyocytes following ischaemic/hypoxic insults. Cell Death. Dis. 2014, 5, e1503. [CrossRef] [PubMed]

76. Zhang, Q.; Hu, H.; Shi, X.; Tang, W. Knockdown of S100P by lentiviral-mediated rnai promotes apoptosis and suppresses the colony-formation ability of gastric cancer cells. Oncol. Rep. 2014, 31, 2344-2350. [CrossRef] [PubMed] 
77. Ke, K.; Shen, J.; Song, Y.; Cao, M.; Lu, H.; Liu, C.; Shen, J.; Li, A.; Huang, J.; Ni, H.; et al. CDK5 contributes to neuronal apoptosis via promoting MEF2D phosphorylation in rat model of intracerebral hemorrhage. J. Mol. Neurosci. 2015, 56, 48-59. [CrossRef] [PubMed]

78. Keenan, M.M.; Liu, B.; Tang, X.; Wu, J.; Cyr, D.; Stevens, R.D.; Ilkayeva, O.; Huang, Z.; Tollini, L.A.; Murphy, S.K.; et al. ACLY and ACC1 regulate hypoxia-induced apoptosis by modulating etv4 via $\alpha$-ketoglutarate. PLoS Genet. 2015, 11, e1005599. [CrossRef] [PubMed]

79. Lei, B.; Wan, B.; Peng, J.; Yang, Y.; Lv, D.; Zhou, X.; Shu, F.; Li, F.; Zhong, L.; Wu, H.; et al. PRPS2 expression correlates with sertoli-cell only syndrome and inhibits the apoptosis of tm4 sertoli cells. J. Urol. 2015, 194, 1491-1497. [CrossRef] [PubMed]

80. Ding, B.; Parmigiani, A.; Yang, C.; Budanov, A.V. Sestrin2 facilitates death receptor-induced apoptosis in lung adenocarcinoma cells through regulation of XIAP degradation. Cell Cycle 2015, 14, 3231-3241. [CrossRef] [PubMed]

81. Zheng, Q.Y.; Cao, Z.H.; Hu, X.B.; Li, G.Q.; Dong, S.F.; Xu, G.L.; Zhang, K.Q. Light/IFN- $\gamma$ triggers $\beta$ cells apoptosis via NF-кB/Bcl2-dependent mitochondrial pathway. J. Cell. Mol. Med. 2016, 20, 1861-1871. [CrossRef] [PubMed]

82. Zhang, L.; Jia, G.; Shi, B.; Ge, G.; Duan, H.; Yang, Y. PRSS8 is downregulated and suppresses tumour growth and metastases in hepatocellular carcinoma. Cell. Physiol. Biochem. 2016, 40, 757-769. [CrossRef] [PubMed]

83. Shao, J.; Wang, L.; Zhong, C.; Qi, R.; Li, Y. AHSA1 regulates proliferation, apoptosis, migration, and invasion of osteosarcoma. Biomed. Pharmacother. 2016, 77, 45-51. [CrossRef] [PubMed]

84. Jourd'heuil, F.L.; Xu, H.; Reilly, T.; McKellar, K.; Alaoui, C.E.; Steppich, J.; Liu, Y.F.; Zhao, W.; Ginnan, R.; David Conti, R.L.-S.; et al. The hemoglobin homolog cytoglobin in smooth muscle inhibits apoptosis and regulates vascular remodeling. Arterioscle. Thromb. Vasc. Biol. 2017, 37, 1944-1955. [CrossRef] [PubMed]

85. Lei, Y.; Wang, S.; Ren, B.; Wang, J.; Chen, J.; Lu, J.; Zhan, S.; Fu, Y.; Huang, L.; Tan, J. CHOP favors endoplasmic reticulum stress-induced apoptosis in hepatocellular carcinoma cells via inhibition of autophagy. PLoS ONE 2017, 12, e0183680. [CrossRef] [PubMed]

86. Liu, D.; Mei, X.; Wang, L.; Yang, X. RhoA inhibits apoptosis and increases proliferation of cultured SPCA1 lung cancer cells. Mol. Med. Rep. 2017, 15, 3963-3968. [CrossRef] [PubMed]

87. Savino, A.M.; Sarno, J.; Trentin, L.; Vieri, M.; Fazio, G.; Bardini, M.; Bugarin, C.; Fossati, G.; Davis, K.L.; Gaipa, G.; et al. The histone deacetylase inhibitor givinostat (ITF2357) exhibits potent anti-tumor activity against CRLF2-rearranged BCP-ALL. Leukemia 2017, 31, 2365-2375. [CrossRef] [PubMed]

88. Huang, Y.; Li, D.S.; Zhang, H.M.; Du, J.; Zhang, G.Q.; Wang, P.Y.; Howard, J.G.; Spindler, R.; Durrant, B.; Olson, M.A. Electroeljaculation and semen cryopreservation in giant pandas. J. Sichuan Teach. Coll. 2000, 21, 238-243.

89. Agarwal, A.; Sharma, R.K. Automation is the key to standardized semen analysis using the automated SQA-V sperm quality analyzer. Fertil. Steril. 2007, 87, 156-162. [CrossRef] [PubMed]

90. Zeng, C.; He, L.; Peng, W.; Ding, L.; Tang, K.; Fang, D.; Zhang, Y. Selection of optimal reference genes for quantitative RT-PCR studies of boar spermatozoa cryopreservation. Cryobiology 2014, 68, 113-121. [CrossRef] [PubMed]

91. Li, J.; Ma, W.; Zeng, P.; Wang, J.; Geng, B.; Yang, J.; Cui, Q. LncTar: A tool for predicting the RNA targets of long noncoding RNAs. Brief. Bioinform. 2015, 16, 806-812. [CrossRef] [PubMed]

92. Kim, D.; Langmead, B.; Salzberg, S.L. HISAT: A fast spliced aligner with low memory requirements. Nat. Methods 2015, 12, 357-360. [CrossRef] [PubMed]

(C) 2018 by the authors. Licensee MDPI, Basel, Switzerland. This article is an open access article distributed under the terms and conditions of the Creative Commons Attribution (CC BY) license (http:/ / creativecommons.org/licenses/by/4.0/). 